\title{
Identification and overexpression of ItnI, a novel gene which confers immunity to the two-component lantibiotic lacticin 3147
}

\author{
Olivia McAuliffe, ${ }^{1}$ Colin Hill ${ }^{1}$ and R. Paul Ross ${ }^{2}$
}

Author for correspondence: Colin Hill. Tel: +353 21 902397. Fax: +353 21 903101. e-mail: c.hill@ucc.ie

\footnotetext{
1 Department of

Microbiology and National Food Biotechnology Centre, University College Cork, Republic of Ireland

2 National Dairy Products Research Centre, Moorepark, Fermoy, Co. Cork, Republic of Ireland
}

\begin{abstract}
Production and immunity of the two-component lantibiotic lacticin 3147 is encoded by the $60.2 \mathrm{~kb}$ lactococcal plasmid pMRC01. A $12.6 \mathrm{~kb}$ region of this plasmid, containing ten genes in two divergently arranged gene clusters, has been subcloned in Lactococcus lactis subsp. cremoris MG1363 and has been shown to confer both lacticin 3147 production and immunity. Further subcloning revealed that the smaller of the two clusters (ItnRIFE) confers immunity. Although the ItnF and $E$ genes are homologous to ABC transporters which confer immunity to other lantibiotics, deletion analysis indicates that they do not play a role in the immunity exhibited by this subclone in L. lactis subsp. cremoris MG1363. Also, a deletion in ItnR (which resembles a family of transcriptional repressors) had no effect on immunity. The remaining gene, Itnl, encodes a 116 amino acid protein with a predicted membrane location which bears no homology to other bacteriocin immunity proteins. Confirmation of its role in immunity was obtained when it was observed that disruption of ItnI resulted in a complete loss of immunity. When ItnI was cloned into the expression vector pMG36e, the resulting construct conferred levels of immunity comparable to pMRC01. This confirmed that under the control of a strong promoter, the Itnl gene product alone is sufficient to confer lacticin immunity. In addition, heterologous expression of ItnI was observed in Enterococcus faecalis OG1X. On cloning ItnI behind a nisin-inducible promoter, it was observed that the level of immunity was dependent on nisin concentration. Using this construct, the authors have demonstrated a potential role for ItnI as food-grade selectable marker. Thus, LtnI appears to represent a new class of lantibiotic immunity proteins.
\end{abstract}

Keywords: lacticin 3147, lantibiotic, immunity, food-grade marker

\section{INTRODUCTION}

The term lantibiotics is used to describe a group of posttranslationally modified peptides which display activity against Gram-positive bacteria (Klaenhammer, 1993; de Vos et al., 1995; Sahl et al., 1995; Sahl \& Bierbaum, 1998). A characteristic of these bacteriocins is the presence of the thioether amino acids lanthionine and/or $\beta$-methylanthionine as well as the dehydrated amino acids 2,3-didehydroalanine and 2,3-didehydrobutyrine, which are formed from serine and threonine, respectively. The primary product of the lantibiotic structural gene(s) is a precursor with an $\mathrm{N}$-terminal leader sequence followed by a C-terminal pro-peptide which

Abbreviations: $A B C, A T P-b i n d i n g ~ c a s s e t t e ; A U$, arbitrary units. undergoes modification. Once modified within the cell, the bacteriocin is secreted by a dedicated transporter and the N-terminal leader is cleaved by a protease (van der Meer et al., 1993). In the case of certain lantibiotics, e.g. lacticin 481 (Rince et al., 1994), activation occurs concomitantly with export as the leader sequence is cleaved by ABC (ATP-binding cassette) transporters which contain a proteolytic domain.

All bacteriocin-producing strains require self-protection mechanisms in order to prevent cell death due to the action of their own bacteriocin(s) (Abee, 1995; Saris et al., 1996). However, despite considerable molecular analysis of the various components involved, the mechanisms of immunity are still poorly understood for most lantibiotic systems. In strains producing nisin, both NisI and NisFEG are suggested to be involved in immunity 
(Kuipers et al., 1993; Engelke et al., 1994; Siegers \& Entian, 1995). NisI is a 245 amino acid protein with a lipoprotein signal sequence which may act to inhibit pore formation by interacting with extracellular nisin (Kuipers et al., 1993). More recently, Qiao et al. (1995) have reported a cytoplasmic membrane location for NisI. The nisFEG gene cluster encodes a multi-component $\mathrm{ABC}$ transporter which is believed to play a role in immunity by transporting the active lantibiotic from the cytoplasmic membrane of immune cells (Siegers \& Entian, 1995). The involvement of multi-component $\mathrm{ABC}$ transporters in lantibiotic immunity is a common feature which has been linked to subtilin produced by Bacillus subtilis (Klein \& Entian, 1994), epidermin produced by Staphylococcus epidermidis (Peschel \& Gotz, 1996) and lacticin 481 produced by Lactococcus lactis (Rince et al., 1997). It has recently been demonstrated that EpiFEG acts by active extrusion of peptide from the cytoplasmic membrane of immune cells (Otto et al., 1998). The mechanism of immunity to the $S$. epidermidis bacteriocin Pep5 appears to involve an interaction between the bacteriocin and a 69 amino acid protein, PepI, at the outer surface of the cytoplasmic membrane (Reis \& Sahl, 1991; Reis et al., 1994; Pag et al., 1999). A protein with $74 \cdot 2 \%$ similarity to PepI, EciI, has been identified in the epicidin 280 gene cluster (Heidrich et al., 1998). Interestingly, the strain which produces epicidin 280, S. epidermidis BN 280, exhibits cross-immunity to Pep5, which suggests a similar molecular mechanism for both of these immunity proteins. In fact, PepI and EciI are more closely related to the immunity proteins of the unmodified peptide (Class II) bacteriocins of Gram-positive bacteria such as lactococcin A (Klaenhammer, 1993; Nissen-Meyer et al., 1993), than to those described for lantibiotics. Recently, a 320 amino acid protein termed Cyll has been shown to confer immunity to the two-component haemolysin/bacteriocin, cytolysin (Coburn et al., 1999; Haas \& Gilmore, 1999).

Lacticin 3147 is a broad-spectrum bacteriocin produced by L. lactis subsp. lactis DPC3147 (Ryan et al., 1996). This two-component, membrane-active bacteriocin acts by selectively dissipating the membrane potential of target organisms (McAuliffe et al., 1998). Recently, the presence of lanthionine residues in both lacticin 3147 peptides has been demonstrated, confirming that lacticin 3147 is a lantibiotic (M. P. Ryan, R. P. Ross \& C. Hill, unpublished results). The genetic determinants responsible for lacticin 3147 production and immunity are encoded on a $60 \cdot 2 \mathrm{~kb}$ plasmid, pMRC01, the sequence of which has been fully elucidated (Dougherty et al., 1998). A $12.6 \mathrm{~kb}$ region of pMRC01 was proposed to encode lacticin 3147 production and immunity based on the homologies of a number of ORFs to genes involved in the production and export of lantibiotics (Klaenhammer, 1993; Jack et al., 1995). This region contains two divergently organized gene clusters, the larger of which was proposed to be responsible for bacteriocin production, modification and export (Fig. 1). It was also noted that the genes which make up the larger cluster had a similar functional organization to those in the cytolysin operon, which encodes another two-component lantibiotic produced by Enterococcus faecalis (Booth et al., 1996; Gilmore et al., 1996). The smaller four-gene cluster was thought to play a role in lacticin 3147 immunity, given that the cluster contains $l t n F$ and ltnE, two genes related to those encoding multi-component $\mathrm{ABC}$ transporters (for reviews see Higgins, 1992; Fath \& Kolter, 1993) found in other lantibiotic immunity systems. However, no biological evidence was presented which supported the proposed role of any of the genes. In this communication, we confirm that the $12.6 \mathrm{~kb}$ region encodes both lacticin 3147 production and immunity, and that the smaller of the two gene clusters is involved in immunity, as proposed. However, contrary to expectations, $\ln F$ and $\ln E$ do not appear to be involved in the immunity exhibited by a subclone containing the four-gene cluster in MG1363. Instead, a novel gene, ltnI, which encodes a 116 amino acid hydrophobic protein, designated LtnI, is responsible for the level of lacticin 3147 immunity observed. Expression studies using a nisin-controlled inducible promoter system indicate that the degree of immunity conferred upon previously sensitive lactococci depends on the amount of LtnI produced in the cell.

\section{METHODS}

Bacterial strains, plasmids and media. Bacterial strains used in this study are listed in Table 1 . All lactococci were grown at $30{ }^{\circ} \mathrm{C}$ without aeration in M17 broth (Oxoid) supplemented with $0.5 \%$ glucose (GM17). Ent. faecalis OG1X was maintained in brain heart infusion broth (Difco) and grown at $37^{\circ} \mathrm{C}$ without aeration. Escherichia coli strains were grown at $37^{\circ} \mathrm{C}$ in LB broth (Sambrook et al., 1989) with vigorous agitation. Plasmids used for cloning included pUC19 (Y anischPerron et al., 1985), an E. coli/L. lactis shuttle vector, pCI372 (Hayes et al., 1990), the expression vector pMG36e (van de Guchte et al., 1989) and the nisin-inducible expression vector pNZ8048 (de Ruyter et al., 1996). LB agar supplemented with X-Gal $\left(40 \mu \mathrm{g} \mathrm{ml}^{-1}\right)$ and IPTG $\left(40 \mu \mathrm{g} \mathrm{ml}^{-1}\right)$ was used for detection of insertional inactivation of the $\alpha$-lacZ gene in pUC19. Antibiotics were used, where indicated, at the following concentrations: ampicillin, $100 \mu \mathrm{g} \mathrm{ml} \mathrm{m}^{-1}$; erythromycin, $100 \mu \mathrm{g} \mathrm{ml}^{-1}$ for E. coli and $5 \mu \mathrm{g} \mathrm{ml} \mathrm{m}^{-1}$ for L. lactis; chloramphenicol, $20 \mu \mathrm{g} \mathrm{ml}^{-1}$ for E. coli and $5 \mu \mathrm{g} \mathrm{ml}^{-1}$ for $L$. lactis. The chemical reagents listed were purchased from Sigma.

Molecular biology techniques. Plasmid DNA was isolated from E. coli strains using the alkaline lysis method (Sambrook et al., 1989) or the QIAGEN column purification kit, and from L. lactis using the method of Anderson \& McKay (1983). pMRC01 DNA (Ryan et al., 1996), which was used as template DNA in PCR, was purified by equilibrium centrifugation in $\mathrm{CsCl}$ /ethidium bromide gradients. L. lactis and E. coli were transformed by electroporation with a Gene-Pulser apparatus (Bio-Rad) as described by Wells et al. (1993) and Sambrook et al. (1989), respectively. Restriction digestion, Klenow treatment and DNA ligations were done according to standard procedures (Sambrook et al., 1989). Restriction enzymes, the Klenow fragment of the E. coli DNA polymerase I and T4 DNA ligase were purchased from New England Biolabs. Restriction-endonuclease-digested DNA was eluted from agarose gels using a GeneClean II kit from Bio101. PCR was 
Table 1. Bacterial strains used in this study

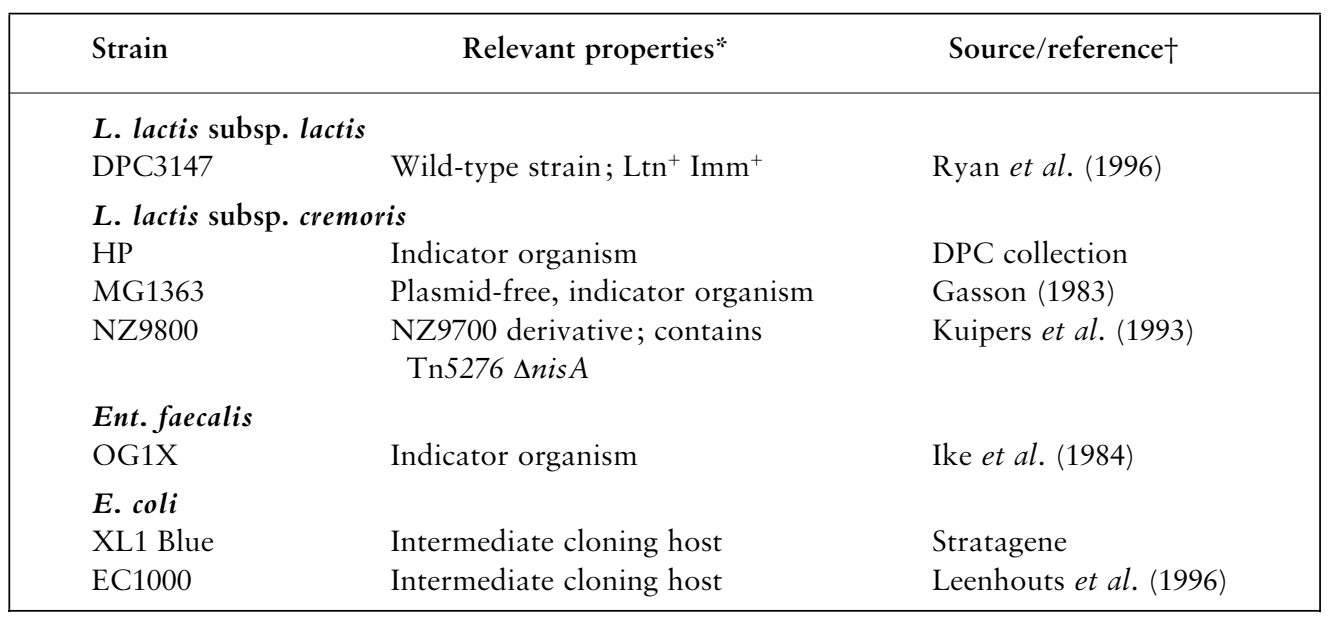

*Ltn, lacticin 3147 production; Imm, immunity to lacticin 3147.

†DPC, Dairy Products Reseach Centre, Moorpark, Fermoy, Co. Cork, Ireland.

Table 2. Primers used in plasmid construction

\begin{tabular}{|c|c|c|c|}
\hline Plasmid* & Primer no. $\dagger$ & Primer sequence $\left(5^{\prime}-3^{\prime}\right) \neq$ & $\begin{array}{c}\text { Temp } \\
\left({ }^{\circ} \mathrm{C}\right)\end{array}$ \\
\hline \multirow[t]{2}{*}{ pOM01 } & $4562(\mathrm{~F})$ & CGGGATCCCTGGTTGTGTTTCAATTTCATT & 55 \\
\hline & $4567(\mathrm{R})$ & CGCGTCGACAACAGAACCTAATATTCAATA & 55 \\
\hline \multirow[t]{2}{*}{ pOM02 (1/2) } & $3951 \mathrm{~b}(\mathrm{~F})$ & AAAGAGCTCTGCGAATAACATCAAGGGAA & 55 \\
\hline & $5144(\mathrm{R})$ & GATGGATCCATTATTATTACTGTTT & 55 \\
\hline \multirow[t]{2}{*}{$(2 / 2)$} & $5145(\mathrm{~F})$ & ATGGATCCATCAGTAGGTAGAACTA & 60 \\
\hline & $5146(\mathrm{R})$ & GCTGTCGACTTAAGTATAGGGCAAT & 60 \\
\hline \multirow[t]{2}{*}{ pOM05 } & $4562(\mathrm{R})$ & & \\
\hline & $5356(\mathrm{~F})$ & CGCGTCGACCATTTCCTTTTTATATTGATT & 55 \\
\hline \multirow{2}{*}{ pOM22 } & $5563(\mathrm{~F})$ & ATGCATGCAACTATACACCTTCTT & 50 \\
\hline & $5562(\mathrm{R})$ & TAT & 50 \\
\hline \multirow[t]{2}{*}{ pOM23 $(1 / 2)$} & $5534(\mathrm{~F})$ & AATGAGCTCACTGGTTGTGTTTCA & 50 \\
\hline & $5533(\mathrm{R})$ & AGGATCCCTAATAGAATCTTGAAA & 50 \\
\hline \multirow[t]{2}{*}{$(2 / 2)$} & $5532(\mathrm{~F})$ & AGGATCCTTTTTACCTACGAAC & 50 \\
\hline & $5531(\mathrm{R})$ & TTTGTCGACCCTATTTTGGTTGTTTT & 50 \\
\hline \multirow[t]{2}{*}{ pOM24 } & $5636(\mathrm{~F})$ & ATTCCATGGAGAATGAAAATAT & 50 \\
\hline & $5562(\mathrm{R})$ & & \\
\hline \multirow[t]{2}{*}{ pOM26 } & $5286(\mathrm{~F})$ & ATGGATCCATGGTTTTATATTATTATCA & 50 \\
\hline & $5531(\mathrm{R})$ & & \\
\hline
\end{tabular}

$* 1 / 2,2 / 2$ refers to plasmids which were constructed from two separate PCR fragments.

†F, forward; R, reverse.

$\ddagger$ Restriction sites in primer sequences are underlined.

performed by following standard procedures using BIOTAQ DNA polymerase (Bioline). The Expand High Fidelity PCR System (Boehringer) was used to generate PCR products for cloning purposes. Thirty cycles were performed with the following conditions: $30 \mathrm{~s}$ at $90{ }^{\circ} \mathrm{C}, 1 \mathrm{~min}$ at $50^{\circ} \mathrm{C}$ and $1 \mathrm{~min}$ at $72{ }^{\circ} \mathrm{C}$. Where longer PCR products were sought, the Expand Long Template PCR System from Boehringer was used according to the manufacturer's instructions. Primers for PCR were synthesized using an Applied Biosystems PCR-MATE DNA synthesizer.
Plasmid construction and mutagenesis. A number of strategies were used to clone and analyse the genes involved in lacticin production and immunity. Plasmid pOM02, containing the entire $12.6 \mathrm{~kb}$ coding region, was constructed by cloning the operon in roughly two equal halves (using fragments generated by Long Template PCR and engineered to contain appropriate cloning sites) into the $\mathrm{SacI} / \mathrm{SalI}$ sites in the multiple cloning site of the vector, pCI372 (Hayes et al., 1990). Plasmid pOM01 contains the smaller four-gene cluster cloned in pCI372 and was constructed using a single $2.9 \mathrm{~kb}$ 


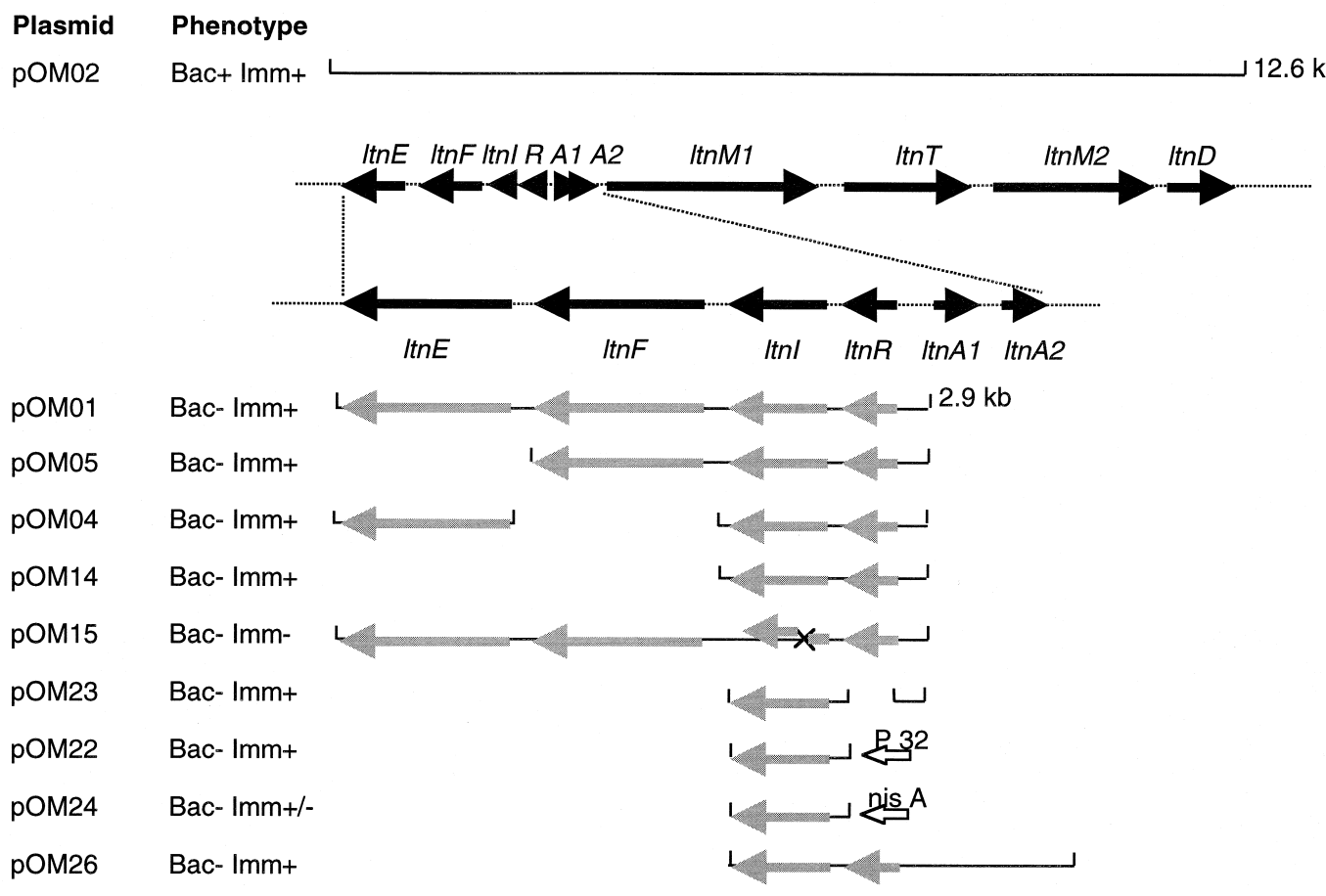

Fig. 1. Schematic representation of the organization of various constructs and the phenotypes associated with these mutated derivatives. Arrows indicate ORFs and the direction of transcription; lines represent parts of the $12.6 \mathrm{~kb}$ fragment remaining in the various subclones. The ' $X$ ' indicates a frameshift mutation at this point; $P 32$ and nisA represent the P32 lactococcal promoter and the nisin-inducible nisA promoter, respectively. Bac and Imm indicate the phenotype for bacteriocin production and immunity of the different constructs, respectively (Imm $+I-$ indicates that the immunity phenotype was dependent on the level of nisin used to induce the nis $A$ promoter).

PCR fragment. Deletion of the $\ln F$ gene in pOM01, to create pOM04, was accomplished by digestion with $\mathrm{XbaI}$ at three sites internal to this gene and subsequent religation. Similarly, pOM14, which contains intact $l t n R$ and $l t n I$, was also created by $X b a I$ digestion and religation. Mutagenesis of $\ln I$ was achieved by cloning the $2.9 \mathrm{~kb}$ insert from pOM01 into pUC19. The resultant plasmid, pOM08, was digested with AflII, the recessed 3 ' ends were filled in with the Klenow fragment from DNA polymerase I, and the plasmid was religated to create pOM 20 . The $2 \cdot 9 \mathrm{~kb}$ insert from this plasmid, now with a frameshift mutation in $l$ tnI, was subcloned into pCI372 to create pOM15. Plasmids pOM22, pOM23, pOM24 and pOM26 were generated by High Fidelity PCR and cloning. Primers used in plasmid construction are listed in Table 2 and all plasmids created in this study are graphically represented in Fig. 1.

Induction of strains with nisA promoter-containing plasmids. L. lactis NZ9800 was transformed by electroporation with the plasmids pNZ8048 and pOM24. The transformation mixes were plated onto GM17 containing antibiotic only (no nisin was included in the plates at this stage). Transformants were initially grown in GM17 broth containing chloroamphenicol $\left(10 \mu \mathrm{g} \mathrm{ml}^{-1}\right)$; on subculturing, strains were induced with levels of purified nisin ranging from 0.5 to $50 \mathrm{ng} \mathrm{ml}^{-1}$ (purified nisin was a kind gift from Michiel Kleerebezem, NIZO, Ede, The Netherlands). Induced overnight cultures were used in the agar-well-diffusion assay to assess the sensitivity of these strains. The same levels of nisin as in liquid media were used in solid media for these assays.

Bacteriocin preparation and assay. Concentrated lacticin 3147 was prepared as described previously (McAuliffe et al., 1999) from supernatant of L. lactis subsp. lactis DPC3147, and the activity determined by critical-dilution assay (Ryan et al., 1996) using a well-diffusion assay. Basically, molten agar was cooled to $48^{\circ} \mathrm{C}$ and seeded with the strain of interest (approx. $2 \times 10^{7}$ fresh overnight-grown cells). The inoculated medium was dispensed into sterile Petri plates, allowed to solidify and dried. Wells (approx. $4.6 \mathrm{~mm}$ diameter) were made in the seeded agar plates. Aliquots $(50 \mu \mathrm{l})$ of a twofold serial dilution of the bacteriocin preparation were dispensed into the wells, and the plates incubated overnight at the appropriate temperature for the strain in question. The arbitrary units (AU) $\mathrm{ml}^{-1}$ were determined as described by Ryan et al. (1996).

Use of lacticin 3147 as a selective agent. L. lactis NZ9800 cells which had been electroporated with pOM24 (LtnI $\left.{ }^{+}\right)$and pNZ8048 $\left(\mathrm{LtnI}^{-}\right)$were resuspended in $1 \mathrm{ml} \mathrm{GM} 17$ broth, or GM17 broth containing $10 \mathrm{ng}$ purified nisin $\mathrm{ml}^{-1}$. After incubation for $2 \mathrm{~h}$ at $30^{\circ} \mathrm{C}$, transformants were plated on GM17 plates containing chloramphenicol $\left(10 \mu \mathrm{g} \mathrm{m}{ }^{-1}\right)$ and lacticin 3147 (250 AU ml $\mathrm{m}^{-1}$ ). An ammonium sulphate precipitation was used as a source of concentrated lacticin 3147.

\section{RESULTS}

\section{Cloning and expression of a region encoding lacticin 3147 production and immunity}

The nucleotide sequence of pMRC01, the plasmid encoding lacticin 3147 production and immunity, has been previously reported (GenBank accession no. AE001272; Dougherty et al., 1998). The bacteriocincoding region was inferred on the basis of homology to 
(a)

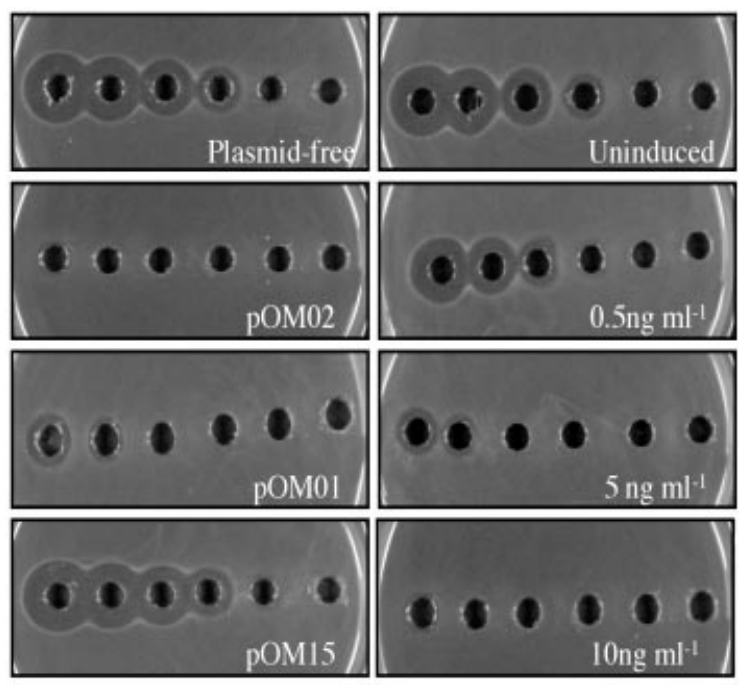

Fig. 2. Inhibitory action of a concentrated lacticin 3147 preparation (left well) and a twofold serial dilution of the preparation (concentration decreasing from left to right) against various clones exhibiting different levels of immunity. (a) L. lactis MG1363 containing the various plasmids indicated; (b) L. lactis NZ9800 containing pOM24 induced with the concentrations of purified nisin indicated.

be located within a $12 \cdot 6 \mathrm{~kb}$ region which contains 10 ORFs arranged in two divergent gene clusters (Fig. 1). This region was PCR amplified and cloned into the E. coli/L. lactis shuttle vector pCI372 (Hayes et al., 1990), using E. coli as an intermediate host. The resultant plasmid, designated pOM02, was introduced into plasmid-free L. lactis subsp. cremoris MG1363 by electroporation, and a number of transformants were examined for their ability to produce lacticin 3147. In a number of independent clones, the plasmid conferred the ability to produce lacticin 3147 on MG1363, and overnight cultures of the transformants produced similar levels of bacteriocin (320 AU ml ${ }^{-1}$ ) as MG1363 transconjugants containing the parental plasmid, pMRC01. pOM02 also conferred a significant level of immunity on MG1363 (Fig. 2), a strain normally quite sensitive to the bacteriocin. This level of immunity was comparable to that conferred by pMRC01 (data not shown). Consequently, it was concluded that this cloned region contained sufficient information to encode both lacticin 3147 production and immunity; this confirmed the region formerly proposed only on the basis of homology comparisons.

\section{ItnI confers immunity on previously sensitive strains}

The theory that the smaller four gene cluster (ItnRIFE) encoded lacticin 3147 immunity was largely based on the fact that two of the four genes, $\ln F$ and $\ln E$, encode proteins with significant sequence similarities to bacterial multi-component $\mathrm{ABC}$ transporters involved in bacteriocin immunity (Peschel \& Gotz, 1996; Rince et al., 1997). To test this hypothesis, a $2.9 \mathrm{~kb}$ region containing all four genes and including the region between $\ln R$ and the first structural gene, $\ln A 1$, was amplified by PCR and cloned into pCI372 to create pOM01 (Fig. 1). MG1363(pOM01) became significantly more immune to lacticin 3147 than the plasmid-free strain (Fig. 2), although the immunity levels exhibited by MG1363(pOM02) were not observed. In order to verify a role for these genes in lacticin immunity, a number of deletion derivatives were constructed (Fig. 1), and transformed into MG1363. The effect of each deletion was assessed by means of the agar-well-diffusion assay using concentrated lacticin 3147. Unexpectedly, those constructs in which $\ln F$ and $\ln E$ were inactivated, both individually (pOM04, pOM05) and in combination (pOM14), conferred the same level of immunity on $L$. lactis MG1363 as pOM01 (data not shown). This confirmed that $\ln F$ and $\ln E$ are not involved in the levels of lacticin 3147 immunity exhibited by MG1363(pOM01). In addition, introducing the plasmid pOM26 (a construct with ltnIRA1A2; Fig. 1) into MG1363 resulted in transformants exhibiting the same level of immunity as strains harbouring pOM14 (ltnRI). To determine if this immunity phenotype was specific to this strain, pOM14, which contains ltnRI, was transformed into the heterologous host Ent. faecalis OG1X, which was then tested for immunity to lacticin 3147. Similar results were obtained in the heterologous host, in that pOM14 also conferred immunity on strain OG1X (data not shown).

Unlike the other putative proteins encoded by the fourgene cluster, LtnI does not display significant similarity to any known protein sequences. In contrast, LtnR, a 79 amino acid protein, is homologous to a number of transcriptional regulators of the repressor type (Fig. 3). Significantly, when plasmid pOM15, constructed from pOM01 by creating a frameshift mutation in $l t n I$, was introduced into MG1363, the immunity phenotype was lost and all transformants were as sensitive to concentrated lacticin 3147 as the plasmid-free strain. This indicated that the product of $\operatorname{ltnI}$ was involved in providing immunity against lacticin 3147 . To confirm this observation, ltnI was cloned downstream of the strong lactococcal promoter in the expression plasmid pMG36e, creating pOM22. This plasmid conferred a significant level of immunity on MG1363, comparable to that seen with pOM02. These experiments confirm that $l n I$ alone, under the control of a strong promoter, is capable of conferring complete immunity on a sensitive strain.

Although there is significant similarity between the mechanisms of immunity described for a number of lantibiotics, to our knowledge there is only one reported case of cross-immunity between lantibiotic producers, i.e. Pep5 and epicidin 280 (Heidrich et al., 1998). The interactions resulting in lacticin 3147 immunity appear to be highly specific, since the various $\mathrm{LtnI}^{+}$constructs created in this study did not confer immunity to a number of other lantibiotics tested, including nisin, lacticin 481 and cytolysin (data not shown). 


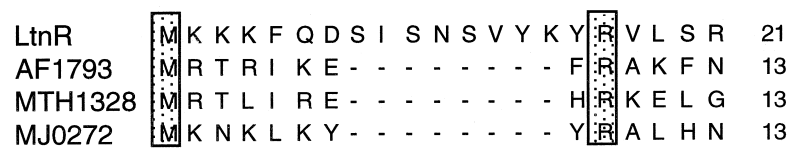

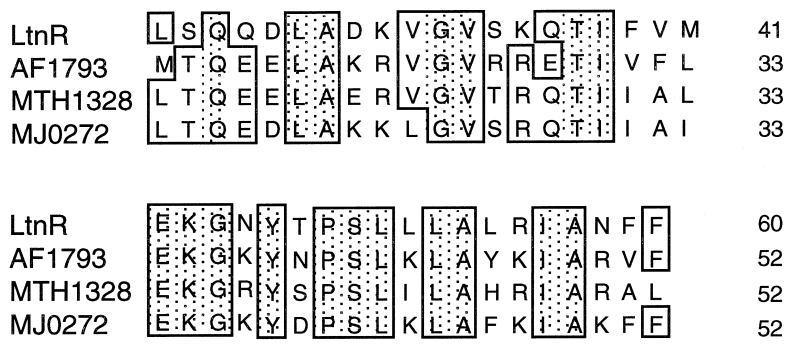

LthR D - V E

AF1793 N - A K I E D I I DEEEL WEKR 71

MTH1328 GREHII E D IfIL DEDG - - A K 69

MJ0272 G-VKII:EDi: I Y Y D DE 66

Fig. 3. Alignment and sequence comparison of the predicted amino acid sequence of LtnR with a number of putative transcriptional regulators of the PBSX (Xre) family. AF1793, produced by Archaeoglobus fulgidus; MTH1328, produced by Methanobacterium thermoautotrophicum; MJ0272, produced by Methanococcus jannaschii. Identical residues in all four proteins are indicated by shading; boxes indicate where residues are identical in three of four proteins. Amino acid residues are numbered; residues 16-35 of AF1793, MTH1328 and MJ0272 contain a helix-turn-helix motif, indicative of DNA-binding sites.

It is possible, given the lower levels of immunity conferred by pOM01 (ltnRIFE) in comparison to pOM02 (containing the complete $12.6 \mathrm{~kb}$ insert), that immunity is a regulated phenomenon, and that $\mathrm{LtnR}$, which is homologous to the PBSX (Xre) family of transcriptional repressors (Wood et al., 1990), may play a role in this regulation. To investigate this possibility, a deletion was made in plasmid pOM14 (ltnRI) to eliminate $\ln R$. An MG1363 transformant harbouring the resulting plasmid, pOM23 (Fig. 1), exhibited the same levels of immunity to lacticin 3147 as MG1363(pOM14), and preliminary mRNA analysis suggests that the level of $l n n I$ transcription is not affected by deletion of $\ln R$ (data not shown).

\section{The level of immunity depends on ItnI transcription}

A fragment encoding $l t n I$ was amplified and cloned into the expression plasmid pNZ8048 under the control of the nisin-inducible nisA promoter (de Ruyter et al., 1996). The resulting plasmid, pOM24 (Fig. 1), was transformed into the expression host L. lactis subsp. cremoris NZ9800 (Kuipers et al., 1993), a strain which contains the nisin operon in the chromosome. This strain does not produce nisin due to a 4 bp deletion in nis $A$, the nisin structural gene. Increasing concentrations of purified nisin can be supplied exogenously to induce the nis A promoter, resulting in increasing levels of gene (a)

M KNENIN T FS ES LF Y S LKE W A EG S AN N YN I L LGL S F IF

VM S S V VFF V T IS T K I G K K DER T T K IS LY S A Y C V LIT L I I

C D I I F P K G Y L I Q P F FM L K Y G F SCLVGGI Y C LL K Y I K

D N K

(b)

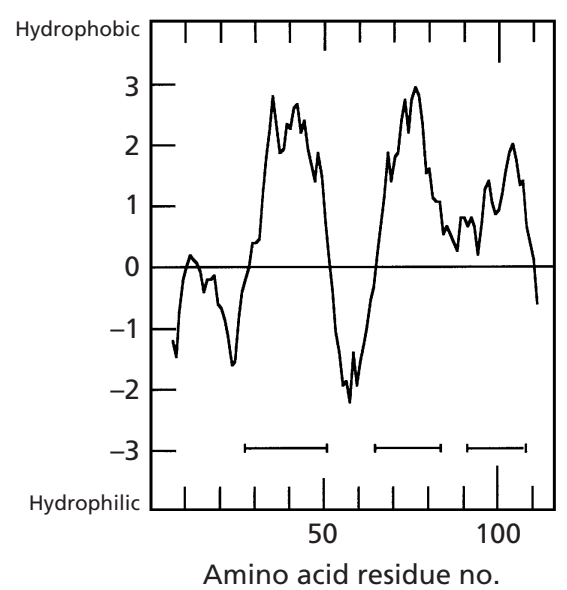

Fig. 4. (a) Predicted amino acid sequence of Ltnl; the box indicates the leucine-zipper motif. (b) Hydrophobicity profile of Ltnl, determined according to the method of Kyte \& Doolittle (1982). Bars indicate hydrophobic segments proposed to be membrane spanning.

expression. Nisin concentrations ranging from 0.5 to $50 \mathrm{ng} \mathrm{ml}^{-1}$ were used to induce expression of $l t n I$ and the strains were assayed as before. As can be seen from Fig. 2 , increasing the level of inducer resulted in a concomitant increase in the level of immunity of NZ9800, and the promoter strength could be adjusted to a point where a level of immunity similar to that seen in strains containing pMRC01 was observed.

\section{Characterization of Ltnl, a novel lantibiotic immunity protein}

Having confirmed a role for LtnI in lacticin immunity, we further examined the predicted amino acid sequence to establish the nature of the protein. As previously mentioned, LtnI did not show any significant sequence similarity to any known proteins. The presence of a leucine zipper motif (Leu-6-Leu-6-Leu-6-Leu; Fig. 4a) in the C-terminus of the 116 amino acid protein suggests that this protein forms homodimers in order to create an active complex. Leucine zipper motifs are usually associated with DNA-binding proteins such as transcription factors (Abel \& Maniatis, 1989); the leucine residues are critical for the dimerization of these proteins. Kyte \& Doolittle (1982) hydrophobicity plots revealed the presence of three hydrophobic domains (aa 30-49, 68-81, 91-112; Fig. 4b), suggesting a transmembrane location for this protein. An immunity protein of this type has not been found previously in other lantibiotic systems. 
Table 3. Comparison of the efficiency of /tn/ with that of an antibiotic-resistance gene as a selectable marker in transformation experiments

\begin{tabular}{|c|c|c|c|c|}
\hline \multirow[t]{2}{*}{ Plasmid } & \multicolumn{4}{|c|}{$\begin{array}{l}\text { No." of transformants of } L \text {. lactis NZ9800 } \\
\text { with the following selection marker } †\end{array}$} \\
\hline & $\mathrm{Cm}$ & $\mathrm{Cm} / \mathrm{Ltn}$ & $\mathrm{Cm} \neq$ & $\operatorname{Ltn} \neq$ \\
\hline pNZ8048 & 243 & 0 & 248 & 0 \\
\hline pOM24 & 283 & 0 & 250 & 194 \\
\hline pOM24\$ & $>300$ & 0 & 290 & 238 \\
\hline
\end{tabular}

$* 10^{-2} \times$ No. of colonies per $\mu$ g DNA.

† Cm, $10 \mu \mathrm{g}$ chloramphenicol $\mathrm{ml}^{-1}$; Ltn, $250 \mathrm{AU}$ lacticin $\mathrm{ml}^{-1}$.

$\ddagger$ Nisin added to selection plates at an inducing concentration of $10 \mathrm{ng} \mathrm{ml}^{-1}$

$\$$ No nisin added to outgrowth medium.

\section{Itnl can be used as a selectable marker}

To evaluate the feasibility of using lacticin 3147 to select for $\mathrm{LtnI}^{+}$transformants in Lactococcus, NZ9800 cells transformed with pOM24 and pNZ8048 ( $\mathrm{LtnI}^{-}$control) were plated onto agar containing lacticin 3147 , and the number of transformants compared to that obtained on the antibiotic plates. Purified nisin was used, in the outgrowth medium and in the selection plates, to induce the nis A promoter for expression of LtnI. The results from a representative experiment are presented in Table 3 ; a number of experiments established that these results were reproducible. Similar numbers of colonies were obtained on both the antibiotic and lacticin plates when the cells were induced with nisin, whereas NZ9800 transformed with pNZ8048 did not yield any colonies on lacticin plates, as expected. Inclusion of nisin in the outgrowth medium only did not allow expression of $l t n I$, presumably because the induction time was too short. All transformants tested from the lacticin selection plates were capable of growth on chloramphenicol and the presence of pOM24 was confirmed in a number of cases, demonstrating the efficiency of lacticin 3147 as a food-grade selective agent.

\section{DISCUSSION}

To date, at least two different mechanisms of lantibiotic immunity have been identified. The presence of putative immunity proteins located at the outer surface of the cytoplasmic membrane, as in the nisin, subtilin and Pep5 systems (Kuipers et al., 1993; Klein \& Entian, 1994; Pag et al., 1999) may result in an interaction with the bacteriocin molecules to prevent pore formation. In addition, $\mathrm{ABC}$ transport systems have been shown to play a role in immunity, possibly by active transport of the bacteriocin from the membrane (Siegers \& Entian, 1995; Peschel \& Gotz, 1996; Rince et al., 1997). In this study, we provide evidence that a novel protein, LtnI, is responsible for immunity to the two-component lanti- biotic lacticin 3147 and describe how this protein is capable of conferring wild-type levels of immunity on a previously sensitive strain. This novel protein may represent a new class of immunity mechanism.

Cloning and expression of a $12.6 \mathrm{~kb}$ fragment of pMRC01 in L. lactis MG1363 confirmed the involvement of genes already identified (Dougherty et al., 1998) in lacticin 3147 production and immunity. It seems unlikely that genes outside of this region are involved in bacteriocin production, as the level of bacteriocin produced by cells harbouring pOM02 was similar to that produced by transconjugants containing pMRC01. The operon-like arrangement of the genes for processing, transport and immunity is a common feature of lantibiotic gene clusters; however, Northern analysis of the lacticin-coding region is required to ascertain if the genes in this region are transcribed as operons. Future work will involve mutational analysis of the various genes in this region, as well as site-directed mutagenesis of the structural genes, in order to gain an insight into the biosynthetic pathway of lacticin 3147 .

Further subcloning and deletion analysis confirmed that the immunity region is associated with ItnRIFE; however, surprisingly, ltnFE did not appear to be involved, as $\ln R I$ conferred the same level of immunity as the four-gene cluster. However, the levels of immunity exhibited by strains harbouring constructs containing these genes under the control of their own promoter were reduced compared to that of the wild-type strain, and also compared to MG1363(pOM02). Similar observations have been reported in other lantibiotic systems. In the nisin system, it was initially observed that expression of the structural gene and the level of immunity were correlated. Kuipers et al. (1993) demonstrated that mutations in the structural gene, nis $A$, resulted in strains which were more sensitive to exogenously applied nisin, and clones expressing the nisin immunity gene, nisI, in the absence of nis A showed quite a low level of immunity. This was shown later to be a result of nisin autoregulation; mature active nisin is essential to activate transcription of the nisin gene cluster by signal transduction at both the nisA and nisFEG promoters, which control the expression of the nisI and nisFEG genes respectively, via the two-component regulator NisRK (Kuipers et al., 1995; Dodd et al., 1996). With Pep5, it was initially observed that mutants harbouring the immunity gene, pepI, without the structural gene, $p e p A$, or with a deleted $p e p A$ were not able to express the Pep5 immunity phenotype and did not produce the pepI gene product (Reis \& Sahl, 1991; Reis et al., 1994). However, recently Pag et al. (1999) have shown that pepI is sufficient for immunity, and that the apparent coupling of immunity to Pep5 production occurs at the level of transcription by the presence of a transcriptional terminator located downstream of pepA which acts to stabilize pepI-containing transcripts. In the lacticin 3147 system, strains containing constructs with $\ln I$ and the lacticin structural genes, $\ln A 1$ and $\ln A 2$, were found not to exhibit the levels of immunity seen in the parent strain. It is possible 
that the level of immunity exhibited by the parent is in some way influenced by production of active lacticin 3147 , and not solely by the presence of the structural genes. In fact, 'wild-type' immunity levels were not observed in any construct containing the native promoter. This may be due to regulatory factors on the parent plasmid which are absent from these constructs, as seen in the Pep5 system, although there is no evidence of a similar transcriptional terminator following the structural genes in the lacticin 3147 coding region. It should, however, be considered that perhaps other genes in the $12.6 \mathrm{~kb}$ bacteriocin region have a role in the levels of immunity exhibited by the producer. Recently, Ra et al. (1999) reported that while NisI has an important function in nisin immunity, cooperation from NisFEG is necessary for full nisin immunity. Similar cooperative interactions may occur in the lacticin 3147 system; this remains to be investigated.

Given that $\ln R$ shows significant homology to a family of transcriptional regulators, it seemed likely that $l n I$ may represent the actual immunity gene. This was confirmed when it was shown that immunity levels similar to those conferred by pMRC01 were exhibited by strains harbouring $l t n I$ cloned under the control of the strong lactococcal promoter in pMG36e. Also, ItnI cloned downstream of the nis A promoter in the nisininducible system was used to demonstrate that the level of immunity is dependent on the level of transcription of ItnI, since increasing the concentration of nisin resulted in an increase in the level of immunity. It could be conceived then that the promoter controlling the transcription of $l t n I$ in the wild-type strain is somehow regulated or induced. Homology comparisons revealed that the gene product of $l t n R$ is similar to the PBSX (Xre) family of transcriptional regulators (Wood et al., 1990; McDonnell et al., 1994; McDonnell \& McConnell, 1994). It has been proposed that the Xre protein regulates transcription of its own gene and divergently transcribed genes by binding to a series of operator sites in the region between these genes. The system has been compared to that of the immunity regions of $\lambda$-type phages, where an autoregulated repressor is divergently transcribed from genes which are also controlled by the repressor (Ptashne, 1992). It is possible that LtnR may act similarly and serve to coordinate expression of the transcripts from the divergent gene clusters in the lacticin 3147 coding region, ensuring that active lacticin 3147 is produced only when immunity has been established. A possible operator site for this putative regulator is the intergenic region between $\ln R$ and $\ln A 1$. This region contains a number of direct and palindromic repeats including an $8 \mathrm{bp}$ inverted repeat in the vicinity of a number of sequences consistent with consensus promoter sequences. The plasmid pOM23, created by deletion of $\ln R$ from pOM14, conferred the same level of immunity on MG1363 as pOM14. This result is in agreement with preliminary mRNA analysis, but not necessarily with the role for LtnR proposed here, as the level of immunity might be expected to increase. It is, however, important to note that other regulatory elements may be involved in the wild-type, which are not present on pOM23, and also that other genes, besides ltnI, may be involved in immunity. Nevertheless, the presence of $\ln R$ appears to provide the only evidence of regulation in the bacteriocin-coding region. A transcriptional regulator has also been identified in the epidermin gene cluster, and has been shown to positively activate gene expression. Peschel et al. (1993) demonstrated that EpiQ, a 205 amino acid protein, binds to palindromic sequences in the epiA promoter region and activates the immunity gene cluster of epiFEG. Genes homologous to the lanR and lanK genes encoding two-component regulatory systems, identified in the operons of other characterized lantibiotics (Engelke et al., 1994; Klein et al., 1993) have not been found in the lacticin 3147 operon, suggesting that a quorum-sensing mechanism (Kleerebezem et al., 1997) does not regulate gene expression in this system.

A role for lacticin 3147 as a food-grade selectable marker has also been demonstrated. It has previously been reported that the parent plasmid, pMRC01, can be electroporated into L. lactis MG1614 using lacticin 3147 as a selection (Coakley et al., 1997). The results presented here show that $\ln I$ alone, at high expression levels, confers a level of immunity which can be used to select transformants in the absence of antibiotic selection. A study performed employing lafl, the lacticin $\mathrm{F}$ immunity gene, as a selectable marker yielded similar results (Allison \& Klaenhammer, 1996); in that case, it was concluded that lafI confers immunity specifically to lactobacilli, and therefore has certain limitations for use as a food-grade marker. In contrast, we have shown that the immunity phenotype conferred by $\ln I$ can be expressed in a heterologous host, namely Ent. faecalis. This may be an important factor in considering ltnI for use in the construction of a food-grade cloning vector.

That this protein is most likely localized at the cytoplasmic membrane is strongly suggested by the presence of three putative transmembrane domains, each consisting of approximately 20 amino acids. While the mode of action of LtnI remains to be determined, the absence of a typical signal sequence implies that LtnI is not a secreted protein, and therefore may be an integral membrane protein where it may serve to hinder the insertion of the bacteriocin molecules in the membrane, or it may interact directly with and inactivate the bacteriocin. There is little sequence similarity between LtnI and CylI (Coburn et al., 1999), the protein which confers immunity to the two-component cytolysin; it will be interesting to determine whether a similar immunity gene is present in the gene system of the twocomponent lantibiotic staphylococcin C55 (Navaratna et al., 1998), especially given the high degree of similarity between this system and lacticin 3147 .

\section{ACKNOWLEDGEMENTS}

The authors thank Maire Ryan and Helen Slattery for their expert assistance, and Michiel Kleerebezem for the kind gift of purified nisin. This work was funded by the Non-Commisioned Food Research Programme, operated by the Irish 
Department of Agriculture, Food and Forestry and supported by national and European funds.

\section{REFERENCES}

Abee, T. (1995). Pore-forming bacteriocins of Gram positive bacteria and self-protection mechanisms of producer organisms. FEMS Microbiol Lett 129, 1-10.

Abel, T. \& Maniatis, T. (1989). Gene regulation: action of leucine zippers. Nature 341, 24-25.

Allison, G. E. \& Klaenhammer, T. R. (1996). Functional analysis of the gene encoding immunity to lacticin F, lafl, and its use as a Lactobacillus-specific, food-grade genetic marker. Appl Environ Microbiol 62, 4450-4460.

Anderson, D. G. \& McKay, L. L. (1983). Simple and rapid method for isolating large plasmid DNA from lactic streptococci. Appl Environ Microbiol 46, 549-552.

Booth, M. C., Bogie, C. P., Sahl, H.-G., Siezen, R. J., Hatter, K. L. \& Gilmore, M. S. (1996). Structural analysis and proteolytic activation of Enterococcus faecalis cytolysin, a novel lantibiotic. Mol Microbiol 21, 1175-1184.

Coakley, M., Fitzgerald, G. F. \& Ross, R. P. (1997). Application and evaluation of the phage resistance- and bacteriocin-encoding plasmid pMRC01 for the improvement of dairy starters cultures. Appl Environ Microbiol 63, 1434-1440.

Coburn, P. S., Hancock, L. E., Booth, M. C. \& Gilmore, M. S. (1999). A novel means of self-protection, unrelated to toxin activation, confers immunity to the bactericidal effects of the Enterococcus faecalis cytolysin. Infect Immun 67, 3339-3347.

Dodd, H. M., Horn, N., Chan, W. C., Giffard, C. J., Bycroft, B. W., Roberts, J. C. K. \& Gasson, M. J. (1996). Molecular analysis of regulation of nisin immunity. Microbiology 142, 2385-2392.

Dougherty, B. A., Hill, C., Weidman, J. F., Richardson, D. R., Venter, J. C. \& Ross, R. P. (1998). Sequence and analysis of the $60 \mathrm{~kb}$ conjugative, bacteriocin-producing plasmid pMRC01 from Lactococcus lactis DPC3147. Mol Microbiol 29, 1029-1038.

Engelke, G., Gutowski-Eckel, Z., Kiesau, P., Siegers, K., Hammelman, M. \& Entian, K.-D. (1994). Regulation of nisin biosynthesis and immunity in Lactococcus lactis 6F3. Appl Environ Microbiol 60, 814-825.

Fath, M. J. \& Kolter, R. (1993). ABC transporters: bacterial exporters. Microbiol Rev 57, 995-1017.

Gasson, M. J. (1983). Plasmid complements of Streptococcus lactis NCDO712 and other lactic streptococci after protoplast curing. J Bacteriol 154, 1-9.

Gilmore, M. S., Skaugen, M. \& Nes, I. F. (1996). Enterococcus faecalis cytolysin and lactocin S of Lactobacillus sake. Antonie Leeuwenhoek 69, 129-138.

van de Guchte, M., van der Vossen, J. M. B. M., Kok, J. \& Venema, G. (1989). Construction of a lactococcal expression vector: expression of hen egg white lysozyme in Lactococcus lactis subsp. lactis. Appl Environ Microbiol 55, 224-228.

Haas, W. \& Gilmore, M. S. (1999). Molecular nature of a novel bacterial toxin: the cytolysin of Enterococcus faecalis. Med Microbiol Immunol 187, 183-190.

Hayes, F., Daly, C. \& Fitzgerald, G. F. (1990). Identification of the minimal replicon of Lactococcus lactis subsp. lactis UC317 plasmid pCI305. Appl Environ Microbiol 56, 202-209.

Heidrich, C., Pag, U., Josten, M., Metzger, J., Jack, R. W., Bierbaum, G., Jung, G. \& Sahl, H.-G. (1998). Isolation, characterization, and heterologous expression of the novel lantibiotic epicidin 280 and analysis of its biosynthetic genes cluster. Appl Environ Microbiol 64, 3140-3146.

Higgins, C. F. (1992). ABC transporters : from microorganisms to man. Annu Rev Cell Biol 8, 67-113.

Ike, Y., Hashimoto, H. \& Clewell, D. B. (1984). Hemolysin of Streptococcus faecalis subspecies zymogenes contributes to virulence in mice. Infect Immun 45, 528-530.

Jack, R. W., Tagg, J. R. \& Ray, B. (1995). Bacteriocins of Gram positive bacteria. Microbiol Rev 59, 171-200.

Klaenhammer, T. R. (1993). Genetics of bacteriocins produced by lactic acid bacteria. FEMS Microbiol Rev 2, 39-86.

Kleerebezem, M., Quadri, L. E., Kuipers, O. P. \& de Vos, W. M. (1997). Quorum sensing by peptide pheromones and twocomponent signal transduction systems in gram-positive bacteria. Mol Microbiol 24, 895-904.

Klein, C. \& Entian, K.-D. (1994). Genes involved in self-protection against the lantibiotic subtilin produced by Bacillus subtilis. Appl Environ Microbiol 60, 2793-2801.

Klein, C., Kaletta, C. \& Entian, K.-D. (1993). Biosynthesis of the lantibiotic subtilin is regulated by a histidine kinase/response regulator system. Appl Environ Microbiol 59, 296-303.

Kuipers, O. P., Beerthuyzen, M. M., Siezen, R. J. \& de Vos, W. M. (1993). Characterisation of the nisin gene cluster nisABTCIPRK of Lactococcus lactis: requirement of expression of the nis $A$ and nisI genes for development of immunity. Eur J Biochem 216, 281-291.

Kuipers, O. P., Beerthuyzen, M. M., Ruyter, P. G. G. A., Leusink, J. L. \& de Vos, W. M. (1995). Autoregulation of nisin biosynthesis in Lactococcus lactis by signal transduction. J Biol Chem 270, 27299-27304.

Kyte, J. \& Doolittle, R. F. (1982). A simple method for displaying the hydropathic character of a protein. J Mol Biol 157, 105-132. Leenhouts, K. J., Buist, G., Bolhuis, A., ten Berge, A., Kiel, J., Mierau, I., Dabrowska, M., Venema, G. \& Kok, J. (1996). A gene system for generating unlabeled gene replacements in bacterial chromosomes. Mol Gen Genet 253, 217-224.

McAuliffe, O., Ryan, M. P., Ross, R. P., Hill, C., Breeuwer, P. \& Abee, T. (1998). Lacticin 3147, a broad-spectrum bacteriocin which selectively dissipates the membrane potential. Appl Environ Microbiol 64, 439-445.

McAuliffe, O., Hill, C. \& Ross, R. P. (1999). Inhibition of Listeria monocytogenes in cottage cheese manufactured with a lacticin 3147-producing starter culture. J Appl Microbiol 86, 251-256.

McDonnell, G. E. \& McConnell, D. J. (1994). Overproduction, isolation and DNA-binding characteristics of Xre, the repressor protein from the Bacillus subtilis defective prophage PBSX. J Bacteriol 176, 5831-5834.

McDonnell, G. E., Wood, H. E., Devine, K. M. \& McConnell, D. J. (1994). Genetic control of bacterial suicide: regulation of the induction of PBSX in Bacillus subtilis. J Bacteriol 176, 5820-5830.

van der Meer, J. R., Polman, J., Beerthuyzen, M. M., Siezen, R. J., Kuipers, O. P. \& de Vos, W. M. (1993). Characterisation of the Lactococcus lactis nisin A operon genes nisP, encoding a subtilisin-like serine protease involved in precursor processing, and nisR, encoding a regulatory protein involved in nisin biosynthesis. J Bacteriol 175, 2578-2588.

Navaratna, M. A. D. B., Sahl, H.-G. \& Tagg, J. R. (1998). Twocomponent anti-Staphylococcus aureus lantibiotic activity produced by Staphylococcus aureus C55. Appl Environ Microbiol 64, 4803-4808.

Nissen-Meyer, J., Havarstein, L. S., Holo, H., Sletten, K. \& Nes, 
I. F. (1993). Association of the lactococcin A immunity factor with the cell membrane: purification and characterisation of the immunity factor. J Gen Microbiol 139, 1503-1509.

Otto, M., Peschel, A. \& Gotz, F. (1998). Producer self-protection against the lantibiotic epidermin by the ABC-transporter EpiFEG of Staphylococcus epidermidis Tu3298. FEMS Microbiol Lett 166, 203-211.

Pag, U., Heidrich, C., Bierbaum, G. \& Sahl, H.-G. (1999). Molecular analysis of expression of the lantibiotic Pep5 immunity phenotype. Appl Environ Microbiol 65, 591-598.

Peschel, A. \& Gotz, F. (1996). Analysis of the Staphylococcus epidermidis genes epiF, $-E$ and $-G$ involved in epidermin immunity. J Bacteriol 178, 531-536.

Peschel, A., Augustin, J., Kupke, T., Stevanovic, S. \& Gotz, F. (1993). Regulation of epidermin biosynthesis by EpiQ. Mol Microbiol 9, 31-39.

Ptashne, M. (editor) (1992). A Genetic Switch. Oxford: Blackwell Scientific Publications.

Qiao, M., Immonen, T., Koponen, O. \& Saris, P. E. J. (1995). The cellular location and effect on nisin immunity of the NisI protein from Lactococcus lactis N8 expressed in Escherichia coli and L. lactis. FEMS Microbiol Lett 144, 89-93.

Ra, R., Beerthuyzen, M. M., de Vos, W. M., Saris, P. E. J. \& Kuipers, O. P. (1999). Effects of gene disruptions in the nisin gene cluster of Lactococcus lactis on nisin production and producer immunity. Microbiology 145, 1227-1233.

Reis, M. \& Sahl, H.-G. (1991). Genetic analysis of the producer selfprotection mechanism ("immunity") against Pep 5. In Nisin and Novel Lantibiotics, pp. 320-332. Edited by G. Jung \& H.-G. Sahl. Leiden, The Netherlands: ESCOM.

Reis, M., Eschblach-Bludau, M., Inglesias-Wind, M. I., Kupke, T. \& Sahl, H.-G. (1994). Producer immunity toward the lantibiotic Pep 5 : identification of the immunity gene pepI and localisation and functional analysis of its gene product. Appl Environ Microbiol 60, 2876-2883.

Rince, A., Dufour, A., LePogam, S., Thuault, D., Bourgeois, C. M. \& LePennec, J.-P. (1994). Cloning, expression, and nucleotide sequence of genes involved in production of lactococcin DR, a bacteriocin from Lactococcus lactis subsp. lactis. Appl Environ Microbiol 60, 1652-1657.

Rince, A., Dufour, A., Uguen, P., LePennec, J.-P. \& Haras, D. (1997). Characterisation of the lacticin 481 operon: the Lacto- coccus lactis genes $l c t F, l c t E$ and $l c t G$ encode a putative $\mathrm{ABC}$ transporter involved in bacteriocin immunity. Appl Environ Microbiol 63, 4252-4260.

de Ruyter, P. G. G. A., Kuipers, O. P. \& de Vos, W. M. (1996). Controlled gene expression systems for Lactococcus lactis with the food-grade inducer nisin. Appl Environ Microbiol 62, 3662-3667.

Ryan, M. P., Rea, M. C., Hill, C. \& Ross, R. P. (1996). An application in cheddar cheese manufacture for a strain of Lactococcus lactis producing a novel broad-spectrum bacteriocin, lacticin 3147 . Appl Environ Microbiol 62, 612-619.

Sahl, H.-G., Jack, R. W. \& Bierbaum, G. (1995). Biosynthesis and biological activities of lantibiotics with unique post-translational modifications. Eur J Biochem 230, 827-853.

Sahl, H.-G. \& Bierbaum, G. (1998). Lantibiotics: biosynthesis and biological activities of uniquely modified peptides from grampositive bacteria. Annu Rev Microbiol 52, 41-79.

Sambrook, J., Fritsch, E. F. \& Maniatis, T. (1989). Molecular Cloning: a Laboratory Manual, 2nd edn. Cold Spring Harbor, NY: Cold Spring Harbor Laboratory.

Saris, P. E. J., Immonen, T., Reis, M. \& Sahl, H.-G. (1996). Immunity to lantibiotics. Antonie Leeuwenhoek 69, 151-159.

Siegers, K. \& Entian, K.-D. (1995). Genes involved in immunity to the lantibiotic nisin produced by Lactococcus lactis 6F3. Appl Environ Microbiol 61, 1082-1089.

de Vos, W. M., Kuipers, O. P., van der Meer, J. R. \& Siezen, R. J. (1995). Maturation pathway of nisin and other lantibiotics: posttranslationally modified antimicrobial peptides exported by Gram-positive bacteria. Mol Microbiol 17, 427-437.

Wells, J. M., Wilson, P. W. \& Page, R. W. F. (1993). Improved cloning vectors and transformation procedure for Lactococcus lactis. J Appl Bacteriol 74, 629-636.

Wood, H. E., Devine, K. M. \& McConnell, D. J. (1990). Characterization of a repressor gene (xre) and a temperature-sensitive allele from the Bacillus subtilis prophage, PBSX. Gene 96, 83-88.

Yanisch-Perron, C., Vieira, J. \& Messing, J. (1985). Improved M13 phage cloning vectors and host strains: nucleotide sequences of the M13mp18 and pUC19 vectors. Gene 33, 103-119.

Received 14 June 1999; revised 4 September 1999; accepted 24 September 1999. 